\title{
On the Self-consciousness of Cultural Security of Ideological and Political Education in College
}

\author{
Suling Wang \\ Department of Marxist-Leninist Theory Research, Luoyang Normal University, Luoyang Henan 471022, China
}

\begin{abstract}
The Eighteenth Congress of the Communist Party has set up a high level of cultural consciousness and cultural confidence to build a Socialist cultural powerful goal. In accordance with the spirit of the Party Central Committee: The work of Ideological and political education has a highly significance in cultural construction. How the college students' ideological and political qualities is directly related to the future fate of the party and the State. In the cultural construction should give full play to the consciousness and advanced of Ideological and political education. Constantly strengthening consciousness of the security of national ideology, the security of socialist core values and the security of basic system of socialism, fully playing the spiritual enlightenment and practice cultivation of ideological and political education and Effort to achieve the grand goal of Socialist cultural powerful.
\end{abstract}

Key words - Self-consciousness of cultural security; Ideological and Political Education; Ideology; the Core socialist value system.

IN the Eighteenth Congress of the Communist Party: "we must adhere to the direction of socialist advanced culture, set up the high cultural self-consciousness and cultural confidence, Striding forward towards the grand goal of building a socialist culture power" ${ }^{[1]}$.To maintain the cultural security is the prerequisite and inevitable requirement in the construction of socialist cultural power. The Fourth Session of the Sixteenth Central Committee of the Party and the Sixth Session of the Seventeenth Central Committee of the Party regard cultural security, political security, economic security and information security as the four national top securities. In accordance with the spirit of the Party Central Committee: The work of Ideological and political education has a highly significance in cultural construction. Hu Jin-tao, General Secretary pointed out that " how the situation of College students ' ideological and political! Moral quality! the scientific and cultural qualities, Not only directly related to the current stage qualities of the Chinese nation, and directly related to the future of the Chinese nation's quality, Especially how to college students ' ideological and political quality is directly related to the future fate of the party and the State" ${ }^{\text {[2] }}$. Ideological and political education in Colleges and universities is characterized with ideology; it should establish the sense and responsibility of self-consciousness of the national cultural security, and play the role of ideological and political education in cultural construction.

\section{Consciousness of Ideological and political education in the security of Socialist ideology}

Because of the huge ambiguity in the definition of "culture", at present, the " cultural consciousness" has a different understanding, The first is that the concept of "culture" used in the article from the current more consistent views: cultural and natural relative, is the sum of material wealth and spiritual wealth created by human beings.

"Cultural self-consciousness" is an important concept proposed by Mr. Fei Xiao-tong as early as 1997 in the second advanced seminar in Sociology Anthropology held at Peking University. Considering the source and development of his "Cultural self-consciousness" thought, he firstly saw the problem of how to keep the culture of the minorities, and then recognized the crisis of Chinese culture. "A long debate about Chinese and Western culture appeared in a variety of ways, which is concluded as the following: under the strong impact of western culture, whether modern Chinese will maintain the original cultural identity or have to be approve Western cultural?" ${ }^{[3]}$ Cultural self-consciousness reflects people's subjective spirit and rational cognition in the cultural construction, cultural evaluation and cultural choice as well as human awareness of their own cultural fate and cultural selfconsciousness in the future, so, self-consciousness of cultural security is the meaning of "cultural self-consciousness". Cultural consciousness embodied in the meaning of culture safety consciousness.

The core of cultural security is the security of ideology, as a part of ideology, ideological and political education should have the responsibility and bear of ideology. Faced with the "non-ideological" attitude deliberately advocated by western developed capitalism countries which is to make every attempt to permeate and subvert our country, and the gradual spread of "weaken the social trend of thought ideology", we should be fully aware of the importance and urgency of the security of national ideology. One side, with the rapid development of economic globalization and expanding international exchanges, cultural aggression of capitalism doesn't stop its step, but continues with new tricks. The "invisible front" of ideology on the placid surface should be focused within our vision. As long as national countries exist, ideological conflicts can hardly be avoided. On the other hand, the Panideological misconceptions in the history and negative issues and its adverse effects in real social transformation cause the gradual spread of "the trend of weaken social ideology"

The difference of between ideological and political education and other forms of education lies in ideology, and its contents are mainly among the ideological concept system. Although they are also represented by knowledge, ideas and other forms of spiritual cultural symbols, they are mainly social normative knowledge of moral, law, values which are related with politics and class. In our country, the socialist 
ideology and its realization has become a cornerstone in maintaining the social order, regulating and managing various aspects of the social relations of production. Once problems arise in the field of ideology, they may lead to social unrest and even loss of power, the disintegration of the Soviet Union is a lesson for us.

In the field of ideology, ideological discourse often directly reflects the researcher's thought, which contains class intention and embodies the subject's spirit. Ideology is a kind of subjective expression, different ideologies have their different subjects who have different spiritual production and life, here different class tendencies. The deepest penetration, most durable and most stable in ideology reflect the expression of the ruling class, the ruling group of the most basic economic and political power, embodies the law and ethics of the power. The ideology of China is different from that of the west, there still exists competition in the ideological field, such as a variety of western culture and Western ideology in different ways, trying to peddle the western centralism, seize the opportune moment to deny the socialist value system; from the different angle of view, echoing a conclusion: capitalism is the highest form of the development of human society. In the process of social transformation in China, varieties of social psychology, social thought and social consciousness form arise because of the complexity of social interests and the diversification of interest subjects. Facing different forms of ideology covert or overt, and the complexity of cultural resources, ideological and political education, as a communication process of ideology, should play the function of cultural choice of Ideological and political education, adhere to the socialist ideology and constantly enrich the content.

Furthermore, different from social common experience and social psychology, the social ideology is a theoretical and systematic thinking. The construction of the mainstream ideology of the society and its implementation not just rely on mandatory indoctrination and the political authority, it should be carried out through the rational authority way to achieve persuasion and emotional appeal. Ideological and political education should play the role of spiritual enlightenment, spread, maintain and enforce the authority of socialist ideology through the internal force of Marx's truth, resort to argument instead of simple sermon, with inner reason not to overcome different views. Marx clearly pointed out: "Theory as long as convincing people, can grasp the masses; and theory as long as thoroughly, can convince people."[4] Especially in the competition and the contest of different ideologies, to become the most legitimate ideology and the most powerful idea in the society, the ruling class must carry out class demonstration and culture implementation for power and profit in spiritual social arrangement, and cultural development and utilization. Ideological and political education must absorb and utilize the rich cultural resources, enhance authority of the socialist ideology.

The authority of ideology is related with not only its contents and explanatory power, but also the authoritative researcher's status, identity, visibility, credibility and moral image. Ideology is the fusion of idea interpretation and behavior norms, once these ideals, beliefs, ethics, legal norms are deepened by their subjects, they will become a kind of social culture personality practice, then, in the spiritual life of ideological field, personal idea embodies certain characters in the world of life, the character's words and deeds are filled with many cultural code of ideology. Ideological and political education is not only a spiritual lecture, but also a realistic example model. Those of ideological subjects associated with the ideological and political education such as the mainstream thinkers' personality charm will virtually educate those educated.

The ideology is not only a conceptual system of reason with the character of cognition, it has the character of moral and political. The most important "cultivating" function of ideological and political education is the spirit shape of the social individual. There is a mutual creation between ideologies and social individual, ideology is the product of human practice, and it shapes the spirit of every social subject. Ideology has the function of regulating and identification of social subjects; it identifies every social subject from his social mission, responsibility, tasks and so on. Ideology is a conceptual symbol that can shape one's social identity, and regulate one's ideological culture from the view of social politics; it creates a certain social subject in a certain meaning. However, ideology not only helps shape the inherent spirit of social subject, it also helps intervene in a subject's social world and changes his daily consciousness in life. In social life, each individual subject lives in the world with an ideological symbol. Any social individual subject has been marked more or less through the process of production, dissemination, implementation of ideology, and the ideologicalization of education is unavoidable, the process of ideological and political education is the direct cultivation and regulation process of social subjects.

The concept of value is the core and essence of the embodiment of ideology, security of values is one of the connotations of cultural security. Maintaining the security of national culture means the maintenance of the core value system, safeguarding their national independence and autonomy of cultural sovereignty, protect them from being damaged and even being subverted.

\section{Consciousness of Ideological and political education in the security of core Socialist value system}

On January 8, a survey titled "Walking on the edge of the ideal and the reality-- a survey of ideological situation of college students in Beijing" was published in the Guangming daily, "the influence of ideological and political course, $52.9 \%$ of the respondents chose 'has certain effect', $7.5 \%$ of the respondents chose the 'impact', those select 'no effect' and 'off' are respectively $16.2 \%$ and $7.2 \%$ ". ${ }^{[5]}$ From these data we can see that there is still a considerable distance in the value construction of college students and the requirement of the core socialist value system. As one of the most important 
factors that affect the national security of the ideological and political education in Colleges, the self- consciousness of core socialist value system cannot be ignored.

Ideological system is often the expressions social ideals, beliefs, values and meaning act of a class, in particular the ruling class. Ideological and political education is the essence of the core socialist value system education. Ideological and political education is not "value neutrality" or "value-free" education, but an education which has a position and a certain value orientation, aims to inculcate and spread the socialist core value system. Six plenary session of the seventeen Communist Party of China pointed out: "We must strengthen the educational guidance, Enhancing social consensus", "to lead the social trend of thought with the socialist core value system, in the whole society to form a unified guiding ideology! The common ideals and beliefs! powerful spiritual force! The basic moral norms!", " Promoting the system of theories of socialism with Chinese characteristics into teaching materials! into the classroom! into the mind! Strengthening and improving the ideological and political education". ${ }^{[6]}$

The most attractive and most persistent pursuit in the core socialist value system is the perfect social ideal in the future, the ideal of socialism with Chinese characteristics under the guidance of Marx theory, because human beings are not only the existence of reality, but also the transcendence existence with rational and thought, and looking forward to a bright future is the characteristic of human beings; human beings are existence of practice, they constantly go beyond the reality through practice. The ideals of socialism with Chinese characteristics determine the direction of socialism with Chinese characteristics, epitomizes the Chinese's value pursuit of "prosperity, democracy, civilization, harmony", the ideal and faith become the spiritual strength which organize and promote Chinese to strive for. Ideological and political education to a certain extent is also the education of Chinese social ideal and faith; it concerns, establishes and maintains social mainstream values.

In reality, the implementation and force of the social mainstream value idea needs certain intermediary -- value norms. The value norms are the embody of social values, which give expression of social ideals and beliefs through the norms of social systems, law, ethics and so on, which constitute a social judgment and evaluation standard of society. These values are not only the requirements of present practical social life, they are also summon for us to realize the would-be social trend and the social mission, duties, tasks which the society has entrusted to us. Ideological and political education shoulders the task to cultivate persons that the society needs; the process of ideological and political education is a process of cultivating and regulating the social subjects.

The value norm of ideological and political education is rooted in a certain social needs, especially the need to maintain social order, they are beyond the special requirements of the individual and specific subjects such as family and group, and manifest as a set of universal social provisions, which constraint, shape and upgrade individual subjects, making them develop to the general orientation of the society. The aim of Ideological and political education is to cultivate builders and successors of Chinese characteristic socialist who go beyond the pursuit of personal gain and are no longer biased to their own small plot of land of the "ego", but the "greater self" putting themselves into the clearer, more fulfilling society, and then upgraded through the ideological and political education. However, the condensation of common ideal first needs to safeguard the realization of individual life value, which determines the importance of individual development in building an ideal society, so it is important to pay attention to personal development. To guide college students to establish the correct values and world outlook and cultivate the active political ideal and social pursuit in them should be on the base of their individual development and self-realization, and the ideological and political education to them should combine the legal protection with rational guide.

According to the survey of "Walking on the edge of the ideal and the reality-of the survey of ideological situation of college students in Beijing", "Current college students' ideals of social and community responsibility tend to be plain and dull". [5] College students' cognition and attention for social ideal and social awareness has largely passive tendency and is vulnerable to the outside world, lacks initiative spirit and deep, abiding interest, therefore, the ideological and political education needs to cultivate their value rationality for the construction of core value. The core Socialist values system is the common political ideal of all Chinese, and it is the unity of the rational cognition and value pursuit of the Chinese society, the value rationality of it is the rationality of the basic tendency of the whole society and the foundation of college students' ideals and beliefs. If construction of core values was lack of the support of value rationality, it will lead them easily affected by the complicated social trends of thought, deviated from the mainstream value of the society, therefore value distortions. Ideological and political education cultivate students' rational ability to understand values and explore the word truths, understand and approve the rationality of current social system, law, ethics and other social norms, in order to promote certain values, critical certain values. Especially nowadays, the global mainstream discourse power is still in the western world, we must discard the false and retain the true, establish our own discourse system which is useful to us and can be accepted by the world through reform and innovation. The current Chinese social ideological trend shows diversity and differences, such as the mainstream of patriotism, collectivism, socialism, and other non-mainstream ideas and concepts. By cultivating students' rational ability to understand the social trend of thought, distinguish what thought we should support and approve, which thought we should criticize and resolve, can the socialist core values play the leading role.

Since the values education is different from the academic activities as the "life" experience, and the construction of values is tightly linked with individual's emotions and interests; in order to strengthen the construction of college students' core values, we must adhere to the principle of combining 
theory and practice in education, cultivating their innovation ability and stable, right values in practice. Since the Party Central Committee, the Ministry of education put forward that all courses in high school ideological and political theory course should strengthen practice, improve the pertinence and effectiveness of teaching, college and universities across the country study and explore model of practice teaching, devoting a high level of enthusiasm. for example, Shanghai Institute of Political Science and Law has established and implemented practice teaching mode of "sense-practice-thinking" with three main forms of experience, practice, research and so on. ${ }^{[7]}$ In a word, practice education should be based on the actual and future value of demand, actual experience of college students, cultivation of practice is the basic point and focus, also it is the main way and the basic path.

What is worth mentioning is that, practice education in ideological and political education must make full use of those personified, externalized and materialized resources of social ideology, and make the salutary influence on college students' values through nurture and rehabilitation These revolutionary leaders, heroes and advanced examples can be said to be "spiritual leaders" in the field of ideology, they cultivate their spiritual homes through their own life portrait work, and they should be models of student learning in a variety of ways, such as visiting, studying and practicing. In addition, the ideology can also constitute a social environment in which people live by means of thought externalization or materialization, such as art works, or even a tombstone, a memorial hall, and in this way, their influence is subtle and deeply rooted in college students.

\section{References}

[1] Hu Jin-tao, Firmly taking the Socialist road with Chinese characteristics socialism with Chinese characteristics to the new victory [N], Newspaper Articles of The people's daily, 2012-11-09.

[2] Selected important documents since the Sixteenth Congress of the Communist Party of China (medium)[z], Beijing: The Central literature Publishing House, 2006:633.

[3] Fei Xiao-tong, The Source and Practical Significance of Cultural Selfconsciousness Thought $[\mathrm{J}]$, Journal of Literature History and philosophy,2003(3):15-16.

[4] Marx Karl, Selected Works of Karl Marx and Frederick Engels:vol.1[M] , Beijing: People's Publishing House,1995(1):9.

[5] Unknown,Walking on the edge of the ideal and the reality-- a survey of ideological situation of college students in Beijing[EB],Electronic Bulletin Board Online, http//www.theory.people.com.cn/n/2013/0108/c49157-20128411.html.

[6] Decision of the CPC Central Committee on deepening the reform of the cultural system to promote socialist cultural development and prosperity of some major issues[EB],Electronic Bulletin Board Online,http://theory.people.com.cn/GB/16018030.html.

[7] Zhang Sen-nian,Construction and practice of "the mode practice teaching of "sence- practice-thinking", [J], Journal of Ideological and Political Education,2011 (7) : 66-69. 